\title{
Tietokulttuurin ulottuvuudet sosiaali- ja terveydenhuollon uudistuvissa organisaatioissa - vuorovaikutteisen tiedolla johtamisen haaste
}

\author{
Hanna Vakkala \& Antti Syväjärvi
}

\begin{abstract}
The dimensions of information culture in social and health care organizations - the challenge of interactive information management
\end{abstract}

This article examines the dimensions of information culture (Choo 2013) in Finnish social and health care. Secondly, we ask how information culture should be developed in the context of reforms. Information culture is defined as interactive, open and value-based activity in organizations, and it can be defined by four dimensions: rule-following, relationship-based, risk-taking and result-oriented. The dimensions are studied based on 223 survey responses from the managers and supervisors in two health care districts. The results show that there is activity in all dimensions, result-oriented gets the slightly highest scores. Result-oriented and relationship-based information cultures are highly valued, but borders and problems in information reliability effect on information usage. Conclusively, supporting information creating and sharing activities and leadership practices are considered important in developing relationship-based and creative information culture in social and health care organizations.

Keywords: information culture, information management, social and health care, reform

\section{JOHDANTO}

Tieto ja tietotoiminta muodostavat organisaatioiden menestymisen ja muutoksen johtamisen kivijalan (esim. Kogut \& Zander 1992; Rytilä 2011; Hislop 2013). Suomessa hallintotieteen ja johtamisen tutkimusalalla aihetta on lähestytty muun muassa tietointensiivisyyden (esim. Maula \& Peltoniemi 2005; Markova 2005), tietojohtamisen (esim. Laihonen ym. 2013) ja tiedolla johtamisen (esim. Virtanen, Stenvall \& Rannisto 2015) käsitteiden kautta.

Tieto ja tiedolla johtaminen ovat nousseet ydinrooliin viime vuosina valmistelluissa, ja edelleen keskusteluissa olevissa, maakuntiin ja sote-organisaatioihin kohdistetuissa uudistuksissa. Kuntien ja kuntayhtymien järjestämän sosiaali- ja terveydenhuollon tavoitellaan keskittyvän aiempaa suurempiin organisaatioihin (sotealueet tai maakunnat). Uudistusten valmistelussa sekä sote-organisaatioiden kehittämisessä tiedon rooli on korostunut erityisesti yhtenäisten tietojärjestelmien sekä sujuvien tieto- ja palveluprosessien tavoittelemisessa, mutta myös palveluiden avaamisessa kilpailulle. Uudistuvissa soteorganisaatioissa vahva professionaalisuus ja hierarkkisuus sekä luotettavan tiedon keskeinen rooli vaikuttavat tietokulttuuriin (Virtanen 2010), eli tietoon liittyviin arvoihin, sääntöihin ja tiedon kanssa toimimiseen (Choo 2006; Hislop 2013). Uudistustilanteissa toiminnan tehokkuutta, toimintakäytänteitä ja esimerkiksi tietojärjestelmiä kehitettäessä onkin oleellista tunnistaa tietokulttuuriin liittyviä piirteitä ja kehittämiskohteita, erityisesti johtamisen näkökulmasta.

Arjen tilanteissa tiedon hyödyntäminen ja luominen toteutuvat yksilötasolla ja yhteisöissä tapahtuvassa vuorovaikutuksessa (Davenport \& 
Prusak 2000). Tieto, tiedolla johtaminen ja tietotoiminta ovat erottamaton osa sosiaali- ja terveydenhuollon organisaatioiden ja työyhteisöjen toimintaa. Ala jo itsessään perustuu tietoon oireista, sairauksista ja hoitokeinoista, ja erikoistuminen on viety hyvin pitkälle, jolloin alaa voidaan pitää tietointensiivisenä (Marjanovic 2011; Markova 2005; Dupuy 2004). Keskeisinä tiedon ominaisuuksina tietointensiivisissä soteorganisaatioissa pidetään muun muassa tiedon ajankohtaisuutta, luotettavuutta ja saatavuutta (Syväjärvi \& Pietiläinen 2016). Sote-organisaatioiden perustoiminnassa tutkittu tieto ja kokemustieto yhdistyvät luontevasti, mutta tieto on luonteeltaan nopeasti vanhenevaa niin potilastyössä kuin johtamisessakin. Tietointensiivisissä palveluorganisaatiossa keskeisessä roolissa ovat asiantuntijat ja asiakassuhteet, eli henkilöstö ja suhdeverkostot (Markova 2005).

Tietointensiivisessä julkisorganisaatiossa tyypillisiksi haasteiksi voivat muodostua tiedon jakaminen, ajantasaisuus ja luotettavuus, erityisesti toiminnan suunnittelun ja johtamisen näkökulmasta (Steventon, Jackson, Hepworth, Curtis \& Everitt 2012; Syväjärvi \& Pietiläinen 2016; Syväjärvi, Leinonen, Kivivirta \& Kesti 2017). Näiden organisaatioiden tietojärjestelmät ja asiantuntijat käsittelevät jatkuvasti suuria määriä tietoa, mikä osaltaan liittyy sähköisiin tiedon säilyttämisen ja jakamisen tapoihin, kuten sähköpostiin, tietojärjestelmiin ja sovelluksiin (esim. Smallwood 2014; Johnston 2015). Tietojärjestelmien toimivuutta ja yhtenäisyyttä kehitetään jatkuvasti ja tiedon arkkitehtuurilla voidaan ylittää raja-aitoja yksiköiden ja erityisalojen välillä, mutta tiedon käyttäminen ja hyödyntäminen toteutuvat edelleen yksilöiden tasolla ja vuorovaikutuksessa (Li \& Feeney 2014). Huomio kiinnittyykin asiantuntijoiden ja työyhteisöjen suuntaan, sosiaaliseen vuorovaikutukseen ja tiedon kanssa toimimisen tapoihin.

Tieto on käsitteenä moniulotteinen ja kontekstisidonnainen, ja lukuisin eri tavoin luokiteltavissa. Perinteisesti tieto on koettu näkyvänä tai piilevänä (Nonaka \& Takeuchi 1995). Näkökulma korostaa, ettei tieto esiinny pelkästään tiedostoina ja ohjeina, vaan tietoa on tekemisen tavoissa, käytänteissä, viestinnässä ja tarinoissa (Lambe 2007; Hislop 2013). Toiminnallisessa tiedon määritelmässä voidaan erottaa myös proseduaalinen tieto, jota usein kuvataan tieto- taidoksi (Kogut \& Zander 1992). Tällöin tietoon liittyy ymmärrys sen tai toivotun päämäärän saavuttamisesta (esim. Becerra-Fernandez \& Sabherwal 2015). Tyypillinen tiedon luokittelun malli on myös arvoketju (The Value Chain of Information), jolloin datasta muodostuu vaiheittain informaatiota, tietoa, ymmärrystä ja lopulta mahdollisesti viisautta (Ackoff 1989). Sote-organisaatioissa datan kehittyminen informaatioksi ja tiedoksi asiantuntijoiden kokemuksen ja vuorovaikutuksen pohjalta onkin nähtävissä päivittäisessä toiminnassa (Rytilä 2011; Barnard, Napier \& Zipperer 2014). Tiedon määritelmään vaikuttavat näin ollen myös muut käytetyt käsitteet ja näkökulmat, mutta käytännössä tiedon luonne ja merkitys muodostuvat aina tilanteiden, käyttötarkoituksen ja sille annetun arvon mukaan. Olennaista on, millaisesta tiedosta on kyse.

Tietoon liittyvässä tutkimuksessa ja kehittämistyössä tietokulttuurin käsite nousee esiin harvakseltaan. Tietokulttuuri (Information / Knowledge Culture) kuvaa tietotoimintaan liittyvää arvoperustaa, sääntöjä ja toimintatapoja organisaatiossa (Curry \& Moore 2003; Choo 2006; Choo 2013; Hislop 2013). Tietokulttuurissa tarkastellaan muun muassa vuorovaikutteisuutta, avoimuutta ja virheitä sallivaa asenneilmastoa tietotoiminnassa. Käsitteellisesti tietokulttuuria pidetään hyvin läheisenä organisaatiokulttuurin kanssa, tietokulttuurin ja -toiminnan ollessa yksi osa organisaatiokulttuuria (Curry \& Moore 2003). Keskeistä tietokulttuurissa on vuorovaikutteisuus ja esimerkiksi Choo (2006) korostaa informaatiosta muodostuvan tietoa yksilöllisissä, jaetuissa ja yhteisöllisissä tulkinnoissa ja vuorovaikutuksessa organisaatiossa. Tietotoiminnalla tarkoitetaan puolestaan tietoon liittyvää vaihdantaa, vuorovaikutusta, keräämistä, louhintaa ja tiedon luomista, eli kaikkea toimintaa tiedon ympärillä.

Tässä tutkimuksessa käyttämämme kokonaisvaltainen ja kulttuurinen näkemys tiedosta painottaa tiedon nivoutuvan kaikkeen organisaatiotoimintaan, toimijasuhteisiin, prosesseihin ja tuloksellisuuteen (Choo 2013; Wehrens, Bekker $\&$ Bal 2014). Tällöin johtamisen nähdään olevan mitä suurimmassa määrin tietotoimintaa, jolloin tieto ja sen hallinta ovat läsnä myös jokaisen julkishallinnollisen ja palveluorganisaation toimijan työkulttuurissa (vrt. van Duivenboden 
\& Thaens 2008). Samanaikaisesti johtamisessa tunnistetaan inhimillinen ulottuvuus ja arkinen ihmisten kohtaaminen (esim. Syväjärvi \& Vakkala 2019), jolloin painottuvat vuorovaikutteisuuden ja ihmisläheisyyden elementit osana tietotoimintaa.

Tavoitteenamme on tuoda esiin sosiaali- ja terveydenhuollon organisaatioiden tietokulttuurin ulottuvuuksia, annettuja merkityksiä sekä niiden painotuksista nousevia kehittämisen edellytyksiä. Jäsennämme ja määritämme tietokulttuuria teorialähtöisesti, hyödyntäen Choon (2006; 2013) esittämää konseptia tietokulttuurin ulottuvuuksista. Kysymme seuraavasti:

Millaisia ovat tietokulttuurin ulottuvuudet sosiaali- ja terveydenhuollossa?

Millaisia kehittämistarpeita tietokulttuuriin kohdentuu rakenteellisten uudistusten kontekstissa?

Tutkimuskohteina ovat kaksi sairaanhoitopiiriä, joissa toteutettiin Työsuojelurahaston rahoittama Inhimillisesti tehokas johtaminen -tutkimushanke. Aineistona toimii sairaanhoitopiirien johdolle ja esimiehille toteutettu kysely ( $n=223$, vastausprosentti 51), jolla keräsimme näkemyksiä tietokulttuurista ja tiedon kanssa toimimisesta. Kysely sisälsi väittämiä sekä avoimia kysymyksiä tiedon kanssa toimimisesta, tietoperustaisuudesta ja tietokulttuurista. Yhdistämme analyysissa laadullista ja määrällistä dataa ja keskitymme tässä yhteydessä tietokulttuurin ulottuvuuksien ja kehittämiskohteiden tarkasteluun koko aineiston tasolla $(\mathrm{n}=223)$. Sairaanhoitopiirikohtaisia tuloksia ei siis eritellä.

Suomalaisessa sosiaali- ja terveydenhuollossa on tutkittu tietojohtamista ja -toimintaa säännöllisesti, painottuen tiedonhallinnan prosesseihin, sekä tiedon hankintaan ja hyödyntämiseen. Useissa eri aiheita käsittelevissä tutkimuksissa on hyödynnetty Choon (2006) tiedonhallinnan prosessimallia, ja Valkonen, Kinnunen ja Saranto (2018) sekä Saranto ja Kuusisto-Niemi (2017) toteavat sen soveltuvan hyvin suomalaisen sotekontekstin tutkimukseen. Tietokulttuuria on kuitenkin tutkittu huomattavasti vähemmän. Jylhä (2017) yhdistää tietokulttuurin (Choo 2006; 2013) käsitteen potilasturvallisuuteen, mutta aineistoa ei analysoida Choon esittämien tietokulttuurin ulottuvuuksien kautta. Kyseistä mallinnusta ei siis tiettävästi ole aiemmin sovellettu empiirisesti suomalaisen sosiaali- ja terveydenhuollon organisaatioiden tutkimuksessa.

Teoriaperustaisena tutkimuksena aloitamme määrittämällä tietokulttuurin käsitteellisesti ja kuvailemme teoreettisena viitekehyksenä käytetyn Choon (2006; 2013) konseptin. Tämän jälkeen tarkastelemme tietokulttuuriin yleisesti vaikuttavia tekijöitä suomalaisissa sote-organisaatioissa. Empiirisessä osassa käsittelemme tietokulttuurin ulottuvuuksia ja kehittämiskohteita tutkituissa organisaatioissa. Tietokulttuurin kehittäminen avoimeen, vuorovaikutteiseen, hyväksyvään ja kehittämistietoa arvostavaan suuntaan koetaan keskeisenä, kun ratkaistaan rakenteisiin siiloutuneen tietotoiminnan ongelmia. Johtopäätöksiin kokoamme keskeiset huomiot ja pohdimme mallinnuksen soveltuvuutta suomalaisen sosiaali- ja terveydenhuollon organisaatioiden tutkimuksessa.

\section{TIETOKULTTUURI KÄSITTEENÄ JA SOSIAALI- JA TERVEYDENHUOLLON ORGANISAATIOISSA}

\section{Tietokulttuurin ulottuvuudet}

Tietokulttuurin määritelmässä lähtökohtana on läheinen käsitteellinen ja toiminnallinen yhteys organisaatiokulttuuriin. Tietokulttuuria pidetäänkin yleisesti osana organisaatiokulttuuria (Hislop 2013). Huomionarvoista on, että tietokulttuurin määrittely on nostettu vain harvoissa lähteissä ydinteemaksi ja tietoon suhtautumista ja tietotoimintaa käsitellään tyypillisesti osana organisaatiokulttuuria. Organisaatiokulttuurilla voikin olla sekä negatiivisia että positiivisia vaikutuksia tietotoimintaan ja -kulttuuriin (Hislop 2013; Liu 2009).

Tietokulttuurissa vuorovaikutus nähdään keskeisenä perustana ja esimerkiksi Choo (2006) kuvaa tietokulttuuria sosiaalisesti rakentuneina ja jaettuina käyttäytymisenä ja arvoina, jotka määrittävät tiedon ja sen hyödyntämisen tapoja. Snowden (2005) erittelee tietokulttuurin arkkityyppejä arvojen, asenteiden ja käyttäytymisen osa-alueista ja niihin liittyvistä positiivisista ja negatiivisista kokemuksista. Curry ja Moore (2003) kuvailevat tehokkaan tietokulttuurin olevan halukkuutta kerätä ja jakaa tietoa, mi- 
kä on tuloksellisen tiedolla johtamisen perusta. Yhteistä näkemyksille on tiedon arvostuksen ohella vuorovaikutteisuuden ja kokemustiedon vahva rooli tietotoiminnassa ja tietokulttuurin määrittelyssä.

Tietokulttuuria tarkastellessa lähtökohdaksi otetaan näin ollen näkemys, jonka mukaan sosiaalisesti rakentuneet ja jaetut arvot ja tiedon kanssa toimiminen määrittävät tiedon merkitystä ja käyttöä (Choo 2006; Oliver 2008). Tiedon merkityksen, yhteisten sääntöjen, toimijoiden käyttäytymisen ja toimintatapojen arvoperustan pohjalta voidaankin jäsentää tietokulttuurien ominaisuuksia. Choo (2013) jäsentää viisi tekijää, jotka määrittävät tietokulttuurin luonnetta: tiedolla johtamisen tavoitteet, tiedon arvot ja normit, tietotarpeet ja tiedon kanssa toimimi- nen, tiedon etsiminen ja luominen sekä tiedon hyödyntäminen.

Choo (emt.) rakentaa tietokulttuurin mallinnuksen tunnetun organisaatiokulttuurin viitekehyksen Competing Values Framework (Cameron \& Quinn 2011) pohjalle. Tietokulttuurin mallinnuksessa käytetään tiedon kanssa toimimista ja tiedon arvoja ja normeja typologian peruslähtökohtina. Tiedon kanssa toimiminen (tietokäyttäytyminen) jaetaan fokuksensa mukaan sisäiseen ja ulkoiseen. Tiedon arvojen ja normien osalta vastakkaisiksi muodostuvat kontrolliin ja yhtenäisyyteen suuntautuminen sekä jakamiseen ja proaktiivisuuteen suuntautuminen. Näiden tekijöiden pohjalta Choo (2013) esittää neljä tietokulttuurin perusulottuvuutta (kuvio 1).

Tiedon arvot ja normit:

jakaminen ja proaktiivisuus

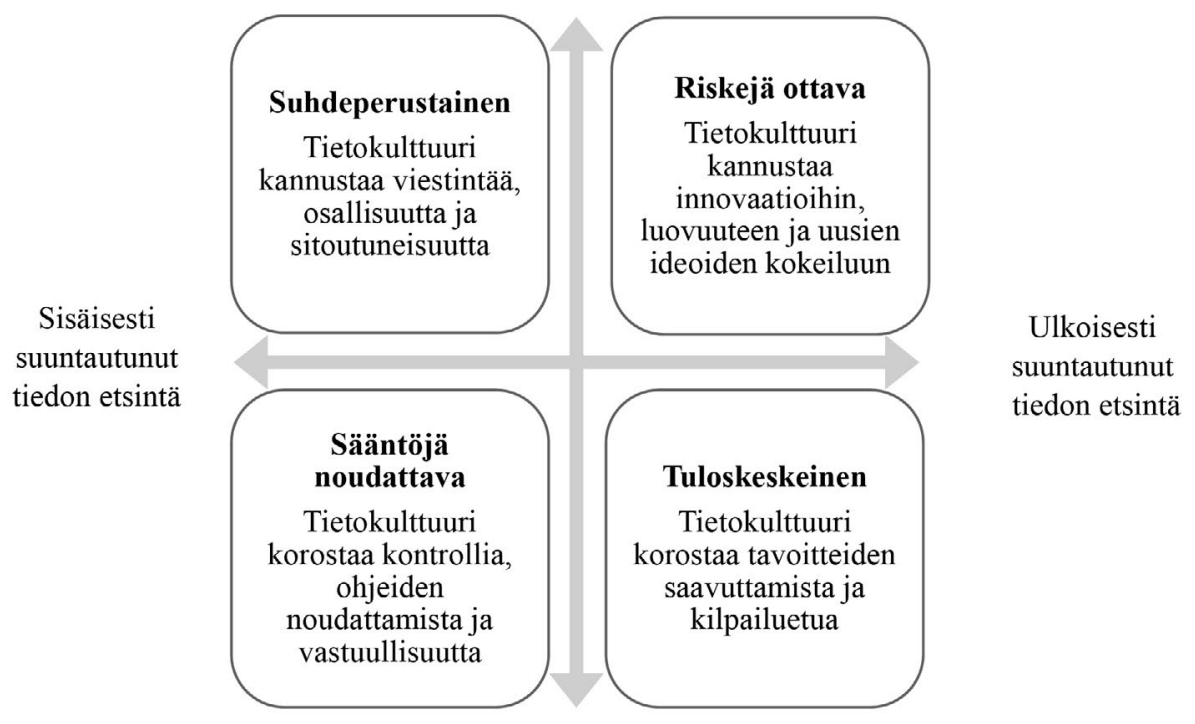

Tiedon arvot ja normit:

kontrolli ja yhtenäisyys

Kuvio 1. Tietokulttuurin pääulottuvuudet (muk. Choo 2013). 
Tuloskeskeisessä tietokulttuurissa tietojohtamisen keskeinen päämäärä on mahdollistaa kilpailuasema ja menestys markkinoilla. Tiedon arvot korostavat kontrollia ja yhtenäisyyttä, ja tietoa etsitään erityisesti ulkopuolelta (asiakkaat, kilpailijat, markkinat). Sääntöjä noudattavassa tietokulttuurissa keskitytään puolestaan enemmän sisäisiin toimintoihin, joilla pyritään vahvistamaan sääntöjä ja toimintatapoja. Täsmällisellä tiedolla tavoitellaan prosessien standardointia ja tehokkuuden lisäämistä, ja tärkeimpinä tietolähteinä pidetään toimintaohjeita, prosessien tuottamaa tietoa ja esimerkiksi teknisen alan tai lakiasiantuntijoiden neuvoja. (Choo 2013.)

Jakamiseen ja proaktiivisuuteen painottuvien tiedon arvojen kulttuurit, eli suhdeperustainen ja riskejä ottava tietokulttuuri korostavat vuorovaikutteisuutta, osallisuutta ja viestintää. Suhdeperustaisessa tietokulttuurissa arvostetaan aloitteellisuutta, yhteistyötä ja tiedon aktiivista luomista ja etsintää. Tiedon fokus on sisäisessä tiedossa, jota on muun muassa työkavereilla, ammatillisilla tai sosiaalisilla ryhmillä ja yleisesti ottaen tiedon lähteinä toimivat sosiaaliset verkostot, niin viralliset kuin epävirallisetkin. Suhdeperustaisessa tietokulttuurissa tiedon käyttäminen lisää osallisuuden innokkuutta ja sitoutuneisuutta, ja painotus on erityisesti työyhteisön ja organisaation sisäisessä toiminnassa sekä virallisissa ja epävirallisissa sosiaalisissa verkostoissa. Riskejä ottavassa tietokulttuurissa tiedon käyttö ja etsintä ovat myös sosiaalisiin verkostoihin perustuvaa, mutta tiedon lähteet ovat enemmän ulkoisia. Riskejä ottavassa tietokulttuurissa arvostetaan luovuutta, uusia innovaatioita ja kokeilevaa toimintatapaa, jolloin tiedon tarkoituksena on määrittää ja arvioida mahdollisuuksia kasvuun, uusiin aluevaltauksiin ja toiminnan innovatiiviseen kehittämiseen. (Choo 2013.)

Neljä ulottuvuutta ja tietokulttuurin tyyppiä ei kuitenkaan tarkoita, että organisaatio sijoittuisi niistä yhteen, vaan tietokulttuuri sisältää elementtejä kaikista. Lisäksi, etenkin suurissa, hajautetuissa tai erilaisten toimialojen organisaatioissa on mahdollista, että tietokulttuurilla on erilaisia painotuksia eri yksiköissä. Choo (2013) kuitenkin esittää hypoteesinomaisesti, että tyypillisesti organisaation tietokulttuuri olisi painottunut kahteen ulottuvuuteen. Mallinnusta hyödyntäneet Vick, Nagano ja Popadiuk (2015) vahvistavat hypoteesin kahdesta dominoivasta ulottuvuudesta, vaikka kaikkien ulottuvuuksien piirteitä olisikin havaittavissa. Hekin (emt.) kuitenkin toteavat tietokulttuurin voivan vaihdella organisaation sisällä: tutkitun yliopiston innovaatioprojektien tiimien kulttuureissa oli tiimikohtaista vaihtelua kaikkien neljän ulottuvuuden välillä.

Choon tietokulttuuri-mallinnukseen viitataan kansainvälisessä tutkimuksessa pääasiassa käsitemäärittelyn näkökulmasta, mutta sitä on sovellettu toistaiseksi niukalti (ks. Lauri, Heidmets \& Virkus 2016). Suomalaisten sote-organisaatioiden tutkimuksessa sitä ei tiettävästi ole tätä kirjoitettaessa empiirisesti käytetty. Kriittisesti tarkastellen mallia voidaan pitää keskiarvoihin perustuvan laskentatapansa vuoksi vahvasti yleistävänä, etenkin jos tyydytään tarkastelemaan tietokulttuuria organisaatiotasolla. Organisaatioiden ja yksiköiden tietokulttuurin täsmällisessä kehittämisessä edellytetäänkin yksikkökohtaisia tuloksia, jotta saavutetaan riittävää tarkkuutta kehittämistoimenpiteille. Toisaalta kuvailevuutensa ansiosta organisaatiotasoisetkin tulokset voivat selittää tuloksellisuus- tai tehokkuustavoitteiden saavuttamista tai saavuttamattomuutta, ja antavat strategisen kehittämisen suuntaviivoja. Tietokulttuurien tekijöiden ja ongelmakohtien tunnistaminen voi myös parantaa edellytyksiä onnistuneelle muutokselle.

\section{Tietokulttuuriin vaikuttavia tekijöitä sote-organisaatioissa}

Organisaatioiden tietokulttuuria ja tiedon kanssa toimimista pidetään tutkimus- ja teoriaperustaisesti yleiseen organisaatiokulttuuriin vahvasti kytkeytyvänä (esim. Hislop 2013), jonka vuoksi kulttuuristen piirteiden tarkastelusta on perusteltua lähteä liikkeelle. Sote-organisaatioiden yleisinä kulttuurisina ominaispiirteinä pidetyt vahva professionaalisuus, arvoperustaisuus, hierarkkinen rakenne ja toiminnan normatiivisuus (esim. Virtanen 2010; Vuori 2005) luovat omanlaisensa kulttuurisen kontekstin tiedon merkitykselle ja johtamiselle. Kulttuuriin sisältyy laaja näkymätön ja tiedostamaton osuus ja kulttuuristen muutosten aikaansaaminen on sosiaali- ja terveydenhuollossa erityisen haastavaa työn luonteen ja toiminnan suurien riskien vuoksi (Kinnunen 2017, 180-181). Sosiaali- ja terveydenhuollon organisaatioissa kulttuuriset 
piirteet ovat nähtävissä muun muassa tiedon kanssa toimimisessa, tietoprosesseissa ja tietoon suhtautumisessa. Vahvat normi-, resurssi- ja informaatio-ohjaus heijastuvat muun muassa professionaalisuuden ja tarkasti jaettujen vastuiden kautta arkiseen toimintaan, myös tietotoimintaan (esim. Rissanen \& Lammintakanen 2017).

Vaikkakin kulttuurisiin piirteisiin vaikuttavat organisaatiokohtainen historia, toimintatavat ja arvot, on nähtävissä muutamia yhteisiä, kansainvälisestikin todennettuja sosiaali- ja terveydenhuollon kulttuurisia tekijöitä, kuten virheiden sallimattomuus tai oikean ja väärän erottamisen arvot (esim. Davies, Nutley \& Mannion 2000; Kinnunen 2017). Kansainvälisissä tietojohtamisen tutkimuksissa ollaan varsin yksimielisiä siitä, että suurimpana esteenä toimivalle tiedon jakamiselle terveydenhuollossa voidaan pitää rankaisevaa ja virheitä sallimatonta kulttuuria (esim. Kim, Newby-Bennett \& Song 2012; Kivinen 2008). Toimintakulttuuri pohjautuu vahvasti alalle tärkeisiin arvoihin, ja jos virheen hintana on esimerkiksi potilaan kuolema tai vammautuminen, tai lievemmässä tilanteessa oireiden pitkittyminen, on yksiselitteistä, miksi kulttuuri on rakentunut estämään virheet ja laiminlyönnit. Virheitä ja epäonnistumisia sallivan toimintatavan hyödyllisyys esimerkiksi potilasturvallisuuden ja palvelutoiminnan laadun kannalta on kuitenkin todettu sekä käytännössä että monin tutkimuksin (esim. Burgess \& Radnor 2013), ja monet sote-organisaatiot soveltavat hukkaa ja aukkoja etsivää Lean-ajattelua. Organisaatiokulttuurin avaaminen virheille käy kuitenkin hitaasti ja on mahdollista, että virhettä selitetään poikkeamalla tai satunnaisuudella, tai siitä ei aina uskalleta kertoa työyhteisössä (Kangas 2018). Tietoaukkojen, pullonkaulojen ja erilaisten virheiden esiin nostaminen on arvokasta tietoa toiminnan kehittämisen kannalta, mutta edellyttää riittävää avoimuutta ja luottamusta.

Tietokulttuuriin vaikuttavat myös toimijoille muodostuneet roolit, jotka määrittyvät yksilön asemaan, tehtävänkuvaan ja sosiaaliseen rooliin perustuen. Esimerkiksi johtavalla lääkärillä, sairaanhoitajalla tai laitosapulaisella on kullakin omalla tavallaan painottunut roolinsa tietotoiminnassa. Ammattiryhmien edustajilla on taipumus välittää tietoa luontevimmin omassa ryhmässään (esim. Currie \& White 2012; Tasselli
2014), mitä edistävät paitsi kokouskäytännöt ja kollegan konsultointi, myös epäviralliset kulttuuriset toimintatavat, kuten lääkärien ja hoitajien omat kahvihuoneet tai -ajat, tai lounasseuran valinta. Lisäksi ammattiryhmien oma kieli ja kommunikaation tapa välittävät epäsuorasti informaatiota siitä, ketkä ryhmään kuuluvat (Kinnunen 2017, 172). Lisäksi ammattiryhmien perinteinen asema hierarkkisessa organisaatiorakenteessa vaikuttaa ryhmien väliseen vuoropuheluun ja tiedonkulkua on viime vuosina avattu muun muassa moniammatillisten tiimien kautta. Kulttuuriset tekijät ovat kuitenkin syvällä toimintatavoissa ja yhteisöllisessä muistissa, ja vahvalla organisaatiokulttuurilla on taipumus korjata yksittäisiä poikkeamia.

Laitinen $(2016,156)$ kuvaa makrotasolle ulottuvan sääntelyn, vakiintuneiden toimintatapojen ja vahvojen ammatillisten normien muodostuvan tietoperustaisuuden vahvistamisen ja muutoskyvykkyyden esteiksi terveydenhuollossa. Vakkala ja Palo (2016) ovat nostaneet keskeisinä sote-organisaatioiden tietokulttuurin ongelmina johtamisen näkökulmasta tiedon luotettavuuden ja saatavuuden, sekä tietojärjestelmien ja tietotoiminnan välineiden toimivuuden, mutta myös tiedon hukkumisen ja hukkaamisen hetket. Muutostilanteessa tietokulttuurit ovat mukana valmisteluvaiheesta alkaen, ja erilaiset tietotoiminnan periaatteet ja tavat voivat luoda paitsi arkisia käytännön haasteita, rajoitteita ja kuiluja, myös syvällisempiä arvojen kohtaamattomuuden ongelmia.

Kehitettäessä tietoprosessien kulkua tulisi professioihin ja asemaan liittyvien roolien näkökulmat ja vaihtelevat tietoperustaisuuden painotukset ottaa lähtökohdaksi, sillä ne voivat kertoa esteistä ja katkoksista tiedon liikkumisessa (esim. Zipperer 2014). Vastaavaan tulokseen on päätynyt Mertala $(2011,221)$ todetessaan "yhdessä tietämisessä" olevan ongelmia etenkin informaatiokatkoksina, päällekkäisinä tehtävinä ja vastuiden epäselkeytenä. Informaatiokatkoksissa tietoprosessista puuttuu toimija tai tieto pysähtyy matkallaan, mikä esimerkiksi potilastyön kannalta voi johtaa pitkittyneisiin oireisiin tai ongelman laajenemiseen. Päällekkäisyyden ongelma on tyypillinen hektisissä tilanteissa, jolloin samaa asiaa tai tehtävää voi käsitellä useampi toimija toisistaan tietämättä. Toisaalta, virheiden välttämiseksi saatetaan joutua varmis- 
telemaan useammaltakin suunnalta, kenen vastuulla jokin asia on, tai onhan se hoidettu. Tällaiset epävarmuustekijät ja tietoprosessien ongelmat vievät aikaa muilta tehtäviltä ja luovat monimutkaisuutta arkeen. (Mertala 2011).

Vuorovaikutteisessa tietotoiminnassa korostuu yksilöiden rooli ja innostus tietotoimijana: onko hän aktiivinen tiedon etsijä ja välittäjä, vai esimerkiksi tietoa odottava, passiivinen työyhteisön jäsen? Aktiivinen ote tietoon on vuorovaikutteisen työyhteisön toimivuuden kannalta varsin olennaista ja tekee tietotoiminnasta samanaikaisesti yksilöllistä ja yhteisöllistä (Rytilä 2011). Esimerkiksi tiedon jakaminen perustuu yksilön harkintaan ja hän voi puntaroida tiedon jakamiseen liittyviä etuja ja kustannuksia, ja pohtia tiedon sosiaalista arvoa (Cyr \& Choo 2010; Ståhle \& Grönroos 2000). Merkitykselliseksi voi nousta, liittyykö ongelmien esilletuontiin leimautumisen, luottamuksen pettämisen tai sosiaalisen aseman hankaloitumisen riskejä. Sujuvien tietoprosessien, eli mahdollisimman luontevasti ja aukottomasti liikkuvan tiedon näkökulmasta keskeistä on, että työyhteisö ja toimintakulttuuri kannustavat tiedon jakamiseen ja työyhteisössä on kykyä ottaa vastaan myös negatiivista tietoa (esim. Vakkala \& Palo 2016).

Vuorovaikutteisuuden painottuessa romahtanut tietotoimijuus voi tuottaa ongelmia. Yksilöt saattavat keskittyä liian vahvasti oman työn tekemiseen ja sulkeutuvat yhteisöltä, jolloin tiedonkulusta muodostuu epäsäännöllistä (Prusak 1997). Tällöin tietotoiminnan merkitys voi perustua lähinnä rakenteisiin, virallisiin yksikkörajoihin ja toimintatavoitteisiin (Syväjärvi, Vakkala \& Stenvall 2013). Kuten Vakkala ja Palo (2016) toteavat, rakenteisiin virallistettu tietotoiminta on jäykkää ja hierarkkista, eikä salli joustavuutta muuttuvissa tilanteissa. Jatkuvissa muutoksissa ei rakenteisiin perustuva tietotoiminta ole kyllin ketterä muuntumaan "sisäsyntyisesti” ja jäykät tiedon liikkumisen rakenteet voivat kovissa tietopaineissa murtua (Syväjärvi ym. 2013). Rakenteellinen tiedon solmukohta voi myös osoittautua hyödyttömäksi esimerkiksi ammattiryhmien ja epävirallisten verkostojen toteuttaman tietotoiminnan vuoksi (Tasselli 2014). Virallistetun tietotoiminnan painottuessa voivat toimijoiden väliset suhteet muodostua hektisessä arjessa myös liian kietoutuneiksi ja toisistaan riippuvaisiksi, jolloin tiedonvaihto saattaa olla keskittynyttä, rajoitettua ja toimijasidonnaista, ja voi syntyä vahva riippuvuus tietoverkostolle keskeisestä toimijasta (Syväjärvi ym. 2013). Tällöin kokonaisuus on haavoittuva: tietopääomassa ja -ketjussa olisi hyvä pyrkiä tasapainoon ja työyhteisön jäsenten aktiiviseen otteeseen tietotoiminnassa.

\section{TUTKIMUKSEN TOTEUTUS JA TULOKSET}

\section{Tutkimusaineiston kerääminen}

Tutkimusaineisto on kerätty Työsuojelurahaston rahoittamassa Inhimillisesti tehokas johtaminen -tutkimushankkeessa (2013-2016). Hankkeeseen osallistuivat Lapin ja Pohjois-Pohjanmaan sairaanhoitopiirien johto ja esimiehet. Aineistona käytetään keväällä 2015 toteutettua, johdolle ja esimiehille kohdennettua kyselyaineistoa, jossa selvitettiin tietokulttuuria ja tiedon kanssa toimimista tutkimuskohteissa. Tutkimus on toteutettu ajankohtana, jolloin Kataisen ja Stubbin hallitusten valmistelema sote-uudistus oli pysähtynyt perustuslaillisiin ongelmiin, ja uusi eduskunta ja Sipilän hallitus aloittivat toimintansa huhtikuun 2015 vaalien jälkeen. Laajempiin soteorganisaatioihin tähtäävää uudistuskeskustelua oli kyselyn toteuttamisvaiheessa käyty jo useiden vuosien ajan.

Esimiehet osallistuivat hankkeeseen kattavasti ja kysely kohdennettiin kaikille esimiesasemassa oleville sekä keski- ja ylimmälle johdolle. Kyselyyn vastasi kaikkiaan 223 vastaajaa ja vastausprosentiksi saatiin 51. Lapin sairaanhoitopiiristä kyselyyn osallistui 95 vastaajaa (54\% johdosta ja esimiehistä), ja Pohjois-Pohjanmaan sairaanhoitopiiristä 128 vastaajaa (49\% johdosta ja esimiehistä). Vastaajat toimivat vastuuyksiköiden ja tulosyksiköiden päälliköinä, yksiköiden ylihoitajina, tulosaluejohtajina sekä keskijohdon ja ylimmän johdon tehtävissä. Yli puolet vastaajista oli toiminut esimiehenä vähintään 10 vuoden ajan, joten vastaajia voidaan pitää kokeneina johtajina. Webropol-kyselyyn vastaaminen oli vapaaehtoista ja siihen kannustettiin sairaanhoitopiirien johtajien läheteviestillä. Kyselyn toteutus linkitettiin hankkeen koulutus- ja kehittämissisältöisiin lähipäiviin, mikä motivoi vastaamista. Vastausprosentteja voidaankin pitää varsin hyvinä. 
Kyselykokonaisuus sisälsi väittämiä (40) ja avoimia kysymyksiä (6), joilla selvitettiin johtajien ja esimiesten näkemyksiä tiedon arvoista, tietokulttuurin osa-alueista, tiedon hukkaamisesta sekä tiedon kanssa toimimisesta. Väittämissä käytettiin Likertin 1-5 asteikkoa (1 täysin eri mieltä, 2 melko eri mieltä, 3 ei samaa eikä eri mieltä, 4 melko samaa mieltä, 5 täysin samaa mieltä). Kysymykset määriteltiin yhteistyössä sairaanhoitopiirien johdon kanssa, jonka vuoksi kysely sisälsi myös muita kuin tietokulttuuriin kohdentuvia kysymyksiä. Kyselylomake laadittiin tutkimushankkeen aikana ja tulokset kokonaisuudessaan on raportoitu kohdeorganisaatioille hankkeen yhteydessä.

Keskitymme tässä artikkelissa muutamiin kyselyn väittämistä. Painotamme kvantitatiivista dataa, joilla tutkittiin tietokulttuurin keskeisiä ulottuvuuksia Choon mallinnusta (kuvio 1) mukaillen. Erittelimme tietokulttuuria koskevat väittämät neljään ulottuvuuteen (sääntöjä noudattava, tuloskeskeinen, suhdeperustainen ja riskejä ottava). Jokaiseen valittiin kolme muuttujaa, jotka edustavat ulottuvuuden ydintekijöitä (Choo 2013; Vick et al 2015). Analyysin selkeyttämiseksi ja mallinnuksen soveltamiseksi suomalaiseen sote-kontekstiin päätettiin alkuperäistä viitekehystä muokata kahden ydintekijän osalta: tiedon käyttö ja tietotoiminta tarpeisiin nähden yhdistettiin, ja tiedon arvoja koskevat kysymykset laajennettiin käsittelemään myös tiedon normeja. Ydintekijöiksi tässä tutkimuksessa muodostuivat näin ollen 1) tiedon arvot ja normit, 2) tiedon käyttö ja tietotoiminta, ja 3) tiedon etsintä ja luominen. Käyttämämme ydintekijät ja ulottuvuudet sekä niihin kohdennetut kyselyn väittämät esitetään taulukossa 1 .

Taulukko 1. Tietokulttuurin osa-alueita ja näkökulmia kuvaavat muuttujat

\begin{tabular}{|c|c|c|c|}
\hline & $\begin{array}{l}\text { Tiedon arvot ja } \\
\text { normit }\end{array}$ & $\begin{array}{l}\text { Tiedon käyttö ja } \\
\text { tietotoiminta }\end{array}$ & $\begin{array}{l}\text { Tiedon etsintä ja } \\
\text { luominen }\end{array}$ \\
\hline $\begin{array}{l}\text { Sääntöjä noudattava: } \\
\text { tietokulttuuri korostaa } \\
\text { kontrollia, ohjeiden } \\
\text { noudattamista ja } \\
\text { vastuullisuutta }\end{array}$ & $\begin{array}{l}\text { Tietotoiminnassa } \\
\text { keskeisiä ovat kontrolli, } \\
\text { selkeät menettelytavat } \\
\text { ja toimintojen } \\
\text { läpinäkyvyys }\end{array}$ & $\begin{array}{l}\text { Tiedon kanssa } \\
\text { toimiminen perustuu } \\
\text { pitkälti rakenteisiin, } \\
\text { kuten osastoihin tai } \\
\text { erikoisaloihin }\end{array}$ & $\begin{array}{l}\text { Tiedon jakaminen ja } \\
\text { luominen tapahtuvat } \\
\text { usein omissa } \\
\text { poteroissa }\end{array}$ \\
\hline $\begin{array}{l}\text { Tuloksiin suuntautunut: } \\
\text { tietokulttuuri korostaa } \\
\text { tavoitteiden saavuttamista } \\
\text { ja kilpailuetua }\end{array}$ & $\begin{array}{l}\text { Toiminnan tulee } \\
\text { olla rationaalista ja } \\
\text { asetettuihin tavoitteisiin } \\
\text { sidottua }\end{array}$ & $\begin{array}{l}\text { Asiakkaiden tai } \\
\text { potilaiden antama } \\
\text { palaute on hyödynnetty } \\
\text { toiminnassamme }\end{array}$ & $\begin{array}{l}\text { Voin luottaa että } \\
\text { saamani tieto on } \\
\text { ajantasaista ja } \\
\text { paikkaansa pitävää }\end{array}$ \\
\hline $\begin{array}{l}\text { Suhdeperustainen: } \\
\text { tietokulttuuri kannustaa } \\
\text { viestintää, osallisuutta ja } \\
\text { sitoutuneisuutta }\end{array}$ & $\begin{array}{l}\text { Tietotoiminta } \\
\text { perustuu vahvaan } \\
\text { kommunikaatioon ja } \\
\text { osallisuuteen }\end{array}$ & $\begin{array}{l}\text { Erilaiset raja-aidat (kuten } \\
\text { ammatit tai yksiköt) eivät } \\
\text { heikennä tietotoimintaa }\end{array}$ & $\begin{array}{l}\text { Tiedonvaihto on } \\
\text { säännöllistä ja jatkuvaa, } \\
\text { jolloin minun ei tarvitse } \\
\text { luottaa vain omiin } \\
\text { havaintoihini }\end{array}$ \\
\hline $\begin{array}{l}\text { Riskejä ottava: } \\
\text { tietokulttuuri kannustaa } \\
\text { innovaatioihin, } \\
\text { luovuuteen ja uusien } \\
\text { ideoiden kokeiluun }\end{array}$ & $\begin{array}{l}\text { Tietotoiminta perustuu } \\
\text { innovatiivisiin ja luoviin } \\
\text { tapoihin }\end{array}$ & $\begin{array}{l}\text { Uusille ideoille ja } \\
\text { menettelytavoille ollaan } \\
\text { avoimia }\end{array}$ & $\begin{array}{l}\text { Tietoa luodaan } \\
\text { aktiivisesti }\end{array}$ \\
\hline
\end{tabular}




\section{Aineiston analyysi}

Aineiston analyysi väittämien osalta on toteutettu yksinkertaisia, mutta tarkoituksenmukaisia menetelmiä, keskiarvoja ja keskihajontaa käyttäen. Analyysin tarkoituksena on osoittaa tietokulttuurin piirteitä ja ulottuvuuksia kuvailevasti, yleiskuvan muodostamiseksi. Tämän vuoksi pitäydytään keskiarvoissa eikä esimerkiksi kausaalisuhteita tarkastella. Muuttujien välisiä riippuvuuksia ulottuvuuksien sisällä olisi voitu testata Cronbachin alphalla tai muilla sisäisiä riippuvuuksia testaavalla menetelmällä, mutta tässä tapauksessa valitut muuttujat viittaavat eri näkökulmiin tietokulttuuriin liittyen, jolloin sisäisten riippuvuuksien tarkastelu ei vastaa teoreettisiin lähtökohtiin. Samasta syystä muuttujia ei ole yhdistetty tai laskettu summamuuttujaksi, jotta niiden erot suhteessa Choon (emt.) viitekehyksen ulottuvuuksiin pysyisivät näkyvillä.

Täydentävässä laadullisen aineiston osiossa selvitimme avoimilla kysymyksillä vastaajien näkemyksiä tietokulttuuria edistävistä ja heikentävistä tekijöistä. Johtajat ja esimiehet listasivat ja kuvailivat asioita varsin monisanaisesti ja innokkaasti, ja valtaosa vastasi avoimiin kysymyksiin. Vastaukset luokiteltiin sisällöllisesti, jotta saadaan kuva voimakkaimmin tietokulttuuriin vaikuttavista tekijöistä. Yksi vastaus saattoi sisältää useampaan luokkaan kuuluvia asioita, jonka vuoksi prosentuaalista edustavuutta ei esitetä avointen vastausten yhteydessä. Luokitusten nimet nousevat suoraan vastausten sisällöistä, kuvaillen vastaajien käyttämiä ilmaisuja. Kategorioita olisi ollut mahdollista rakentaa myös seuraavalle, ylemmälle tasolle, mutta tällöin vastauksien sisällöt olisivat uponneet pääluokkien alle. Kuvailevuuden säilyttämiseksi ne koottiin mainintoina.

\section{Tietokulttuurin ulottuvuudet tutkimuskohteissa}

Tietokulttuurin ulottuvuuksia mittaavat muuttujat analysoitiin keskiarvon ja keskihajonnan avulla (taulukko 2). Analyysi osoittaa muuttujien sisällä olevan valtaosin merkittävästi hajontaa, mikä kertoo vastaajien vaihtelevista käsityksistä tietokulttuuria koskevissa asioissa. Toisaalta vaihtelua on myös muuttujien välillä keskiarvoissa, mitä voidaan pitää merkkinä tulos- ten luotettavuudesta. Kysymyksiin on vastattu ahkerasti (221-222 vastaajaa) kokonaisvastaajamäärän ollessa 223.

Muuttujien keskiarvoista on summattu vertailuluku, jota käytetään ulottuvuuksien keskinäisessä vertailussa. Voimakkaimpana tietoon liittyvänä arvona ja normina näyttäisi nousevan rationaalisuus ja tavoitteisiin sitominen (ka $4,40)$. Tietotoiminnassa on kaksi vahvaa osaaluetta, rakenteisiin perustuminen ja asiakkailta saatavan palautteen hyödyntäminen. Huomionarvoista on, että tiedon etsinnän ja luomisen näkökulmat saavat hieman muita heikompia tuloksia.

Tulosten visuaaliseksi hahmottamiseksi on taulukon 2 luvut asetettu säteittäiseen kaavioon Choon (2013) esimerkin mukaisesti (kuvio 2). Pisteet ovat keskiarvoja ja niitä yhdistävien viivojen värit kuvaavat tietokulttuurin kolmea näkökulmaa. Tulosten asettuminen säteiden asteikolle kertoo neljän tietokulttuurin ulottuvuuden (sääntöjä noudattava, tuloksiin suuntautunut, suhdeperustainen ja riskejä ottava) tasosta tutkimuskohteiden yhteisessä aineistossa. Esitystavassa on yhdistetty molempien sairaanhoitopiirien tulokset, sillä niiden väliset erot ovat suhteellisen pieniä eivätkä vaikuta merkittävästi kokonaisuuteen.

Choon ulottuvuuksia tarkastellen vahvin vertailuluku on tässä aineistossa tuloksiin suuntautuneella tietokulttuurilla $(11,51)$. Toisaalta tässä ulottuvuudessa tiedon ajantasaisuudessa ja luotettavuudessa - mikä on tulosorientaation näkökulmasta varsin keskeistä - nähdään olevan puutteita (ka 3,31). Ero toiseksi voimakkaimpaan ulottuvuuteen, sääntöjä noudattavaan tietokulttuuriin $(10,85)$ ei ole suuri, ja kolmantena tulee riskejä ottava tietokulttuuri (10.12). Pienimpään lukemaan jää suhdeperustainen tietokulttuuri, jonka vertailuluku on vain 8,99 . Tuleekin pohtia kriittisesti, voidaanko tällä perusteella asettaa ulottuvuuksia järjestykseen, sillä erot ovat suhteellisen pieniä ja voivat heilahtaa herkästi, esimerkiksi pienin muuttujavaihdoksin. Ulottuvuuksien määrittelyssä painottuukin teoriasidonnaisuus muuttujien valinnassa, mutta kokonaisuutena ulottuvuuksien keskinäistä asemoitumista tulee pitää lähinnä suuntaa-antavana.

Toisin kuin Choo $(2013,778)$ tyypillisenä tuloksena esittää, tutkimuskohteissamme ei nou- 
Taulukko 2. Muuttujien keskiarvo ja keskihajonta (keskiarvon vaihteluväli 1 - 5)

\begin{tabular}{|c|c|c|c|}
\hline Tietokulttuurin ulottuvuudet ja muuttujat & Keskiarvo & Keski-hajonta & $n$ \\
\hline \multicolumn{4}{|l|}{ Sääntöjä noudattava } \\
\hline $\begin{array}{l}\text { Tietotoiminnassa keskeisiä ovat kontrolli, selkeät } \\
\text { menettelytavat ja toimintojen läpinäkyvyys }\end{array}$ & 3,61 & ,920 & 222 \\
\hline $\begin{array}{l}\text { Tiedon kanssa toimiminen perustuu pitkälti rakenteisiin, } \\
\text { kuten osastoihin tai erikoisaloihin }\end{array}$ & 3,77 & 816 & 222 \\
\hline $\begin{array}{l}\text { Tiedon jakaminen ja luominen tapahtuvat usein omissa } \\
\text { poteroissa }\end{array}$ & 3,47 & ,987 & 222 \\
\hline Vertailuluku, keskiarvojen summa & 10,85 & & \\
\hline \multicolumn{4}{|l|}{ Tuloksiin suuntautunut } \\
\hline $\begin{array}{l}\text { Toiminnan tulee olla rationaalista ja asetettuihin } \\
\text { tavoitteisiin sidottua }\end{array}$ & 4,40 & 650 & 223 \\
\hline $\begin{array}{l}\text { Asiakkaiden tai potilaiden antama palaute on hyödynnetty } \\
\text { toiminnassamme }\end{array}$ & 3,80 & 914 & 221 \\
\hline $\begin{array}{l}\text { Voin luottaa että saamani tieto on ajantasaista ja } \\
\text { paikkaansa pitävää }\end{array}$ & 3,31 & 1,004 & 223 \\
\hline Vertailuluku, keskiarvojen summa & 11,51 & & \\
\hline \multicolumn{4}{|l|}{ Suhdeperustainen } \\
\hline $\begin{array}{l}\text { Tietotoiminta perustuu vahvaan kommunikaatioon ja } \\
\text { osallisuuteen }\end{array}$ & 3,61 & ,990 & 222 \\
\hline $\begin{array}{l}\text { Erilaiset raja-aidat (kuten ammatit tai yksiköt) eivät } \\
\text { heikennä tietotoimintaa }\end{array}$ & 2,38 & 1,031 & 221 \\
\hline $\begin{array}{l}\text { Tiedonvaihto on säännöllistä ja jatkuvaa, jolloin minun ei } \\
\text { tarvitse luottaa vain omiin havaintoihini }\end{array}$ & 3,00 & 0,988 & 222 \\
\hline Vertailuluku, keskiarvojen summa & 8,99 & & \\
\hline \multicolumn{4}{|l|}{ Riskejä ottava } \\
\hline Tietotoiminta perustuu innovatiivisiin ja luoviin tapoihin & 3,25 & 1,009 & 223 \\
\hline Uusille ideoille ja menettelytavoille ollaan avoimia & 3,30 & ,952 & 223 \\
\hline Tietoa luodaan aktiivisesti & 3,57 & 869 & 221 \\
\hline Vertailuluku, keskiarvojen summa & 10,12 & & \\
\hline
\end{tabular}

se selvästi esiin kahta dominoivaa ulottuvuutta. Ulottuvuuksien keskinäiset erot vertailuluvuissa jäävät suhteellisen pieniksi, joskin neljäs (suhdeperustainen) erottuu pienimmällä luvullaan. Myöskään Choon (emt.) esittämä elinkaariajatteluun pohjautuva hypoteesi siitä, että aloittavassa organisaatiossa painottuisi riskien ottaminen, josta voidaan kehittyä suhde- ja sääntöperustaisuuden kautta tulosorientaatioon, ei vaikuta pätevän suomalaisiin sote-organisaatioihin.

Kiinnostavaa on, että ulottuvuuksien välillä on nähtävissä eroja tietokulttuurin toiminnalli- sissa näkökulmissa. Esimerkiksi tiedon arvot ja normit saavat pääasiassa vahvoja tuloksia, mutta tiedon luominen heikompia. Tämä voi viitata vaihtelevasti painottuneisiin arvostuksiin ja toimintatapoihin tietotoiminnan eri osa-alueilla. Tulosta voi myös selittää tiedon ja tietotoiminnan kehittyvä rooli sote-organisaatioissa ja luovuuden hyödyntämisen kehittämistarpeiden tiedostaminen. Esimerkiksi, mikäli organisaatiossa on rakennettu käytäntöjä hukan poistamiseen Leanin periaatteita seuraten, kuten toisessa tutkimuskohteessamme, on mahdollista että 


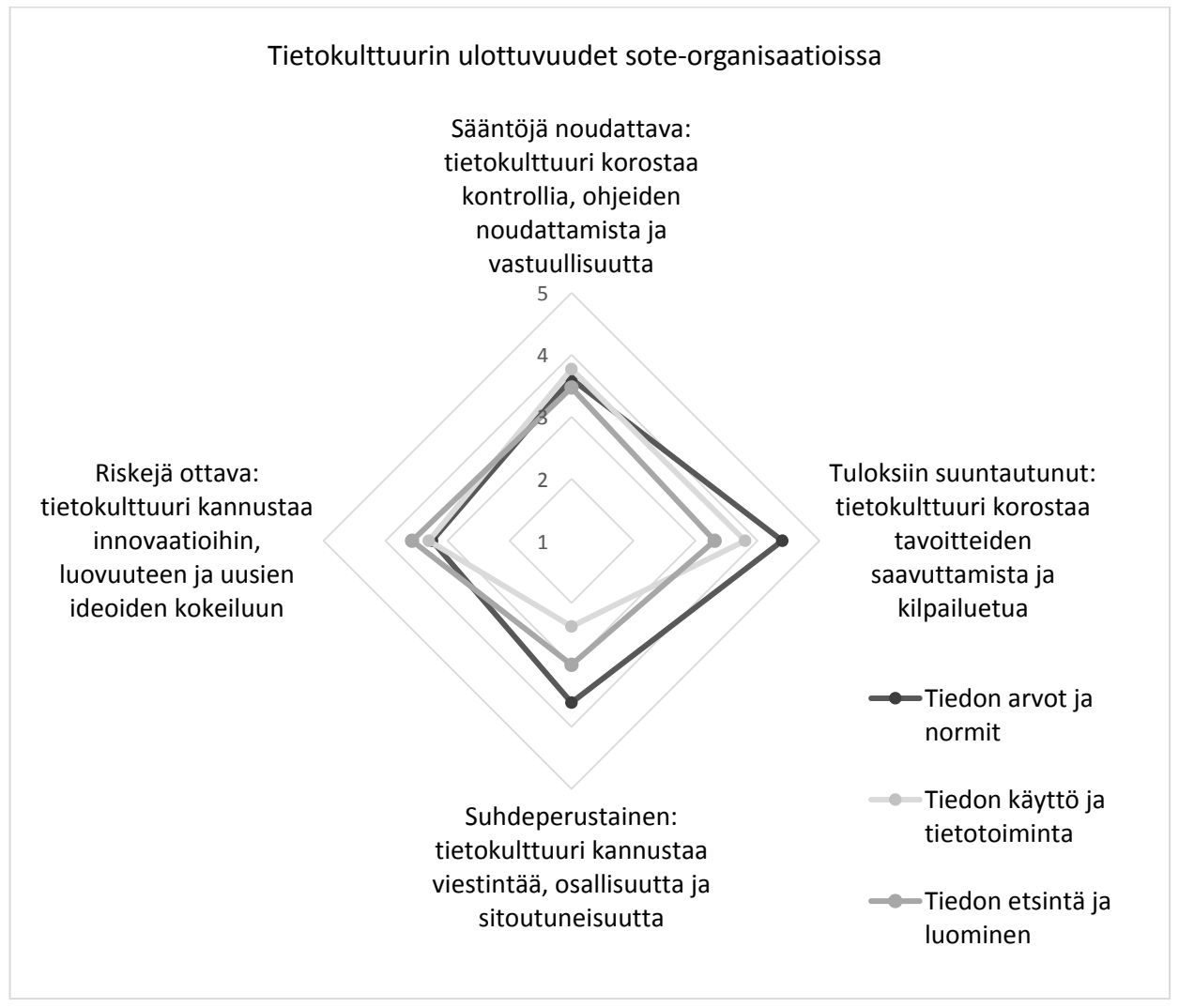

Kuvio 2. Tietokulttuurin ulottuvuudet sosiaali- ja terveydenhuollon organisaatioissa

kehittämisideoihin ja myös virheitä koskevaan tietoon suhtaudutaan suopeammin - ainakin niissä yksiköissä, missä uudet käytännöt ovat vakiintumisvaiheessa. Ulottuvuuksien kokonaiskuva antaakin kiinnostavaa, kuvailevaa tietoa organisaatiotasolla, mutta toimiala- tai yksikkökohtaisessa tutkimuksessa päästäisiin vahvemmin kiinni tulosten vaihteluun ja sen syihin.

\section{Tietokulttuuria edistäviä ja heikentäviä tekijöitä}

Laadullisessa aineistossamme tietokulttuuria edistävinä tekijöinä pidetään vahvimmin ilmapiirin avoimuutta, läpinäkyvyyttä ja vuorovaikutteisuutta (54 mainintaa). Nämä vastaukset sisältävät useimmiten vähintään kaksi edellä mainituista tekijöistä, monissa kaikki kolme asiaa. Yleisimmin mainittuihin tekijöihin liittyvät luottamus ja yhteiset pelisäännöt, sekä kes- kusteleva ympäristö, jossa virheistä ei rangaista. Kaikkiaan organisaatio- ja toimintakulttuurisiin tekijöihin viitataan valtaosassa vastauksista, mikä tekee siitä vahvan osa-alueen tietotoiminnan kehittämisen näkökulmasta. Hyvää tietokulttuuria edistävät vastaajien mielestä myös tiedon laadun, saatavuuden ja ajantasaisuuden hyvä taso. Lisäksi keskeiseen rooliin nousi vahva johtajuus ja näyttöön perustuva johtaminen.

"Ennen kuin tietokulttuuri on automaattinen osa toimintaa, olisi hyvä miettiä omaa ja alaisten tiedontarvetta, omaa toimintatapaa - vaatiiko se muutosta. Hyvä johtaminen ja toimintatavat leviävät."

Vastaavasti tietokulttuuria heikentävinä tekijöinä mainitaan usein tietotoimintaan liittyviä asioita, niin yksilöllisiä kuin yhteisöllisiäkin. Tietotulva ja monet tietokanavat voivat osaltaan 
Taulukko 3. Tietokulttuuria edistäviä ja heikentäviä tekijöitä, avointen vastausten luokittelu

\begin{tabular}{|l|l|}
\hline Hyvää tietokulttuuria edistäviä tekijöitä, top 6 & Tietokulttuuria heikentäviä tekijöitä, top 6 \\
\hline $\begin{array}{l}\text { Ilmapiirin avoimuus, läpinäkyvyys ja } \\
\text { vuorovaikutteisuus }\end{array}$ & $\begin{array}{l}\text { Tiedon vaikea saatavuus ja epäkäytännölliset } \\
\text { tiedotuskanavat }\end{array}$ \\
\hline $\begin{array}{l}\text { Helppo tiedon saatavuus ja käytettävyys } \\
30 \text { mainintaa }\end{array}$ & $\begin{array}{l}\text { Tiedon panttaaminen } \\
24 \text { mainintaa }\end{array}$ \\
\hline $\begin{array}{l}\text { Luottamus ja luotettava tieto } \\
28 \text { mainintaa }\end{array}$ & $\begin{array}{l}\text { Tiedon epäluotettavuus } \\
21 \text { mainintaa }\end{array}$ \\
\hline $\begin{array}{l}\text { Yhteiset pelisäännöt ja ohjeet esim. tiedon } \\
\text { jakamiseen }\end{array}$ & $\begin{array}{l}\text { Vastustava, epäluuloinen ilmapiiri } \\
25 \text { mainintaa }\end{array}$ \\
\hline $\begin{array}{l}\text { Keskusteleva toimintaympäristö, virheiden } \\
\text { salliminen } \\
18 \text { mainintaa }\end{array}$ & $\begin{array}{l}\text { Välinpitämättömyys, asenneongelmat } \\
16 \text { mainintaa }\end{array}$ \\
\hline $\begin{array}{l}\text { Vahva johtajuus, näyttöön perustuva johtaminen } \\
16 \text { mainintaa }\end{array}$ & $\begin{array}{l}\text { Raja-aidat, byrokratia } \\
15 \text { mainintaa }\end{array}$ \\
\hline
\end{tabular}

vaikeuttaa olennaisen tiedon saatavuutta, ja vaatimukset muun muassa tarkoituksenmukaisia, ajantasaisia tietojärjestelmiä kohtaan nousevat selkeästi esiin. Tätä useammin vastauksissa kuvataan kuitenkin tiedon jakamisen ongelmien, välinpitämättömyyden ja huonon keskusteluilmapiirin hiljentävän tietokulttuuria ja aiheuttavan osaltaan tiedon panttaamista. Myös johtamiskulttuuri ja -toimintatavat saavat kritiikkiä.

"Epäselvä toimintakonsepti, huono yhteistyö ja "vanhat tavat on enemmän kuin kopallinen uusia" filosofia, mm."

"Tietoa kerätään, mutta sitä ei osata suodattaa ja hyödyntää. Osaamattomuus kaiken kaikkiaan. Huono tiedotus. Tieto pitää kerätä useasta eri tietolähteestä eivätkä tietojärjestelmät keskustele keskenään. Ajantasainen tiedon siirtyminen puutteellista tämän takia.”

Kysyimme myös, millainen olisi ihanteellinen toimintakulttuuri sote-organisaatioissa tietotoiminnan suhteen. Vastauksissa kuvattiin ideaalisesti toimivia järjestelmiä, luotettavaa tietoa ja avointa tiedon jakamista. Lisäksi useissa vastauksissa nostettiin esiin yhteisiä, jaettuja periaatteita ja toimintaohjeita tietojärjestelmiin, -prosesseihin ja tiedon käyttöön liittyen. Esiin nostettiin myös aktiiviseen tietotoimijuuteen liittyviä edellytyksiä ja tarpeita.
"Yhteneväiset tietojärjestelmät, jossa löytyy toiminnan tunnusluvut ja ajantasainen seurantajärjestelmä. Henkilöstö kaikilla tasoilla osaa hyödyntää oleellisen tiedon. Organisaatiossa on osaamista tiedon hallinnassa ja tuottamisprosessissa. Tiedottamisessa on ymmärretty ihmisten erilaiset tavat vastaanottaa tietoa. Tiedon jakaminen tarkoituksenmukaisesti, hyvä vuorovaikutus ja kommunikointi."

"Ei ole ylivertaista tietäjää eikä myöskään kaiken tiedon hallitsevaa osaajaa! On vain joukon tieto ja osaaminen - toisella yksilöllä enemmän ja toisella hieman vähemmän. Hyvässä tietokulttuurissa ne joilla on antavat ja ne joille ihan niin paljoa ei ole annettu vastaanottavat!"

Huomio vuorovaikutteisuuden merkityksestä tietotoiminnan osaamiseen ja sitä kautta sujuvaan tietokulttuuriin liittyen on olennainen, ja tiivistää tietoperustaisuuden lähtökohdat. Hyvin spesifeistä erityisosaamisista koostuvissa sote-organisaatioissa on jo lähtökohtaisesti eroja yksilöllisessä osaamisessa, ja vuorovaikutteisen johtamisen tehtävänä onkin saada erityisosaamiset ja vahvuudet toimimaan tarkoituksenmukaisesti yhteen, tilanteiden kulloinkin edellyttämällä tavalla. Kyse ei siis ole tietotoiminnan valmiuksien tasapuolistamisessa tai "tasoittamisessa" kaikkien toimijoiden kesken, vaan keino- 
jen rakentamisessa ja kehittämisessä vuorovaikutteisen, luottamusta herättävään monitoimijaisuuteen. Vastaavan toteaa Jalonen $(2015,61)$, korostaen moniäänisyyden, intressiristiriitojen ja tietoperustaisten valintojen yhteensovittamista tiedolla johtamisessa. Vuorovaikutteinen tietotoiminta on näin ollen sosiaalisia taitoja, ihmisten kunnioittamista ja tasapuolisuuteen pyrkimistä, niin johtajien kuin henkilöstönkin näkökulmasta.

"Pitää luoda inhimillinen matala johtamisorganisaatio jossa on tarkkaan rakennettu tietoorganisaatio osaajineen. Henkilöstön ammatillinen osaaminen ja muut kyvykkyydet on kartoitettu ja paitsi osaamista myös muita kyvykkyyksiä hyödynnetään. Työskentely on tiimityöskentelyä, mielellään moniammatillista ja tiimeille jaetaan vastuuta. Autoritaarinen äyskäröivä johtamistyyli eliminoidaan. Yksi perusarvoista on ihmisen kunnioittaminen. Ihmisen, kaikissa tehtävissään, onnistumisissaan ja epäonnistumisissaan."

Johtajuuden keskeinen rooli hyvän tietokulttuurin mahdollistajana nousee vahvasti esiin niin teoreettisissa lähtökohdissa kuin aineistossakin. Kuten Curry ja Moore (2003) toteavat, tarvitaan osallistuvaa, näyttöön perustuvaa johtamistapaa, jotta tietokulttuurin merkitys nousisi esiin ja voisi kehittyä. Aineistossa keskeiseksi hyvän tietokulttuurin edellytykseksi noussut vuorovaikutus rakentuu arvostavalla, ihmisläheisellä johtamisotteella, mikä puolestaan lisää luottamusta ja tasapuolisuuden kokemuksia työyhteisössä (Syväjärvi \& Vakkala 2019). Tätä kautta onnistunut tietokulttuuri kytkeytyy myös hyvinvointiin työssä, kokemuksellisuuteen ja autenttisuuteen. Autenttisuus ja kokemuksellisuus haastavat huomioimaan, että koetut "todellisuutemme" voivat olla erilaisia ja tilanteet voivat saada työyhteisössä monia eri tulkintoja. Tällöin johtajalta tarvitaan tasapainottavaa ja vuorovaikutteista roolia, jotta merkitykset muodostuisivat yhteisen ymmärryksen kautta - eivät pinnallisten tekijöiden, epäluotettavan tiedon tai yksilöiden tunteiden värittämien tulkintojen pohjalta (Pietiläinen \& Salmi 2016).

Laajemmasta näkökulmasta vuorovaikutteisuus kytkeytyy myös rajapintojen ylittämiseen ja aitojen madaltamiseen. Johtajien rooli on keskeinen myös tiedon - niin yksiköiden, erityisalojen kuin organisaatioidenkin - rajapintojen ylittämisessä, mikä on keskeinen tavoite soteorganisaatioiden uudistuksissa. Kyse on paljolti julkisorganisaatioiden rajoja ylittävästä asiakasja johtamistiedon hallinnasta sekä toimijoiden liikkumavarasta suhteessa tietoon (vrt. Syväjärvi ym. 2017), mutta myös tiedon omistajuuden ja luotettavuuden kysymyksistä.

Lopulta korostuu, millaisia merkityksiä ja sisältöjä johtajat antavat tietotoiminnalleen, joilla puolestaan ainakin osittain rakennetaan tietokulttuuria sekä nykyisissä että tulevissa sote-organisaatioissa. Tietokulttuuriset merkitykset ja sisällöt tarkoittavat muun muassa sitä mihin omassa toiminnassa uskotaan, mistä ollaan kiinnostuneita ja ylipäätänsä millaisia asenteita alan osaajilla ja sote-johtajilla on tietoa kohtaan (vrt. Pynes \& Lombardi 2011, 122-128). Edellä mainitut asiat haastavat oppimaan kokemuksista, pohtimaan toimintamalleja, kokeilemaan uudenlaisia käytänteitä ja ylittämään perinteisiä rajoja sekä arkkitehtuureja, mutta myös avaamaan toisille omia johtamisen tietoperustaisuuksia tai kulttuurisia käytänteitä. Esimerkiksi van Duivenboden ja Thaens (2008) sekä Virtanen, Stenvall ja Rannisto (2015) ovat korostaneet sekä kulttuurista että päätöksentekijöiden asenteiden muutosta julkisorganisaatioissa. Tietotoiminnan rajoja luovien esteiden ylittäminen ei näin ollen ole ratkaistavissa pelkästään tietojärjestelmien yhtenäistämisellä ja tietokantojen avaamisella eri toimijoille. Laajemmin kyse on motivaatiosta toimia tietoperustaisesti ja kyvystä uusintaa omia toimintatapoja tiedon kanssa toimimisessa, jolloin huomio kohdentuu paitsi riittäviin tietotoiminnan valmiuksiin, myös vuorovaikutteiseen ja ihmisläheiseen johtamisotteeseen.

\section{JOHTOPÄÄTÖKSET}

Tässä artikkelissa tarkoituksena on ollut selvittää tietokulttuurin ulottuvuuksia sote-organisaatioissa ja siihen kohdistuvia kehittämistarpeita rakenteellisten uudistusten kontekstissa. Olemme lähestyneet tietokulttuuria hallinnon tutkimuksen kentässä teorialähtöisesti, tuoden tietokulttuurin käsitteenä hallintotieteelliseen kes- 
kusteluun ja testaten Choon (2013) viitekehyksen toimivuutta suomalaisten sote-organisaatioiden tietokulttuurin jäsentämisessä.

Lähtökohtaisesti oletimme, että organisaation tietokulttuuri voidaan Choon (emt.) viitekehykseen pohjautuen profiloida ulottuvuuksien kautta, jolloin voidaan löytää tietokulttuurin painotuksia ja kehittämiskohteita. Viitekehyksen soveltamisessa olennaista on ollut tunnistaa tutkimuskohteiden tietokulttuuriin vaikuttavia arvoja ja tietotoiminnan perusperiaatteita. Aikaisemman tutkimustiedon perusteella sote-organisaation tietokulttuuria olisi yleisellä tasolla mahdollista kuvata sääntöjen noudattamisen kulttuurina, jossa faktapohjainen tieto ja tarkat säännöt ohjaavat toimintaa, ja jossa vuorovaikutukseen pitkälti vaikuttaa professionaalinen kulttuuriperusta ja -historia, sekä ammattiryhmien erot ja hierarkkisuus (Kivinen 2008; vrt. Curry \& Moore 2003). Tulostemme mukaan sääntöjen noudattaminen tiedon arvoissa ja merkityksessä on kyllä keskeistä, mutta tietokulttuurissa korostuvat myös tuloskeskeisyys ja riskien ottaminen, mikä sisältää myös luovuutta ja aktiivisuutta tiedon luomisessa. Neljänneksi vahvin - eli heikoin - ulottuvuus oli suhdeperustainen tietokulttuuri, joka sekin kuitenkin sai kohtalaisen merkittävän tuloksen.

Tutkimuksen tulosten mukaan eniten kehitettävää nähdään tietotoiminnan vuorovaikutteisuudessa ja raja-aitojen ylittämisessä. Tietoperustaisuus on tieto- ja osaamisintensiivisissä sote-organisaatioissa luontevaa, mutta vuorovaikutuksen keskeisyyden ja haasteiden vuoksi se ei kuitenkaan toteudu aina tarkoituksenmukaisella tavalla. Teoreettisesti organisaatiokulttuurilla ja tietokulttuurilla on erittäin vahva yhteys (esim. Curry \& Moore 2003), ja myös aineistossa kuvailtiin tietokulttuuria edistäviä tekijöitä monilta osin organisaatio- ja toimintakulttuurin elementtien ja ilmenemispiirteiden kautta. Tietokulttuuria heikentävissä tekijöissä painotus on kuitenkin enemmän tietotoimintaan ja asenteisiin liittyvissä asioissa, niin yhteisö- kuin yksilötasollakin. Keskeisenä huomiona nousee vahva yhteys vuorovaikutukseen ja tietoperustaisuuteen, jotka kytkeytyvät moniin tietoon liittyviin käytännön toimintoihin, ja niistä onkin löydettävissä konkreettisia kehittämisen keinoja vastaamaan muuttuviin sisäisiin ja asiakaslähtöisiin tarpeisiin sote-organisaatioissa.
Tulosten mukaan tarvitaan menetelmiä ja johtamiskäytäntöjä, joilla sosiaali- ja terveydenhuollon tietokulttuuria tulisi - ja olisi mahdollista - kehittää kohti suhdeperustaisempaa, mutta myös riskejä ottavaa, luovuuteen kannustavaa ja innovoivaa tietotoimintaa. Suhdeperustainen tietokulttuuri rakentuu vuorovaikutteisuudelle ja tietotoimijoiden verkostoille, ja painottaa sisäistä tietoa toiminnan kehittämisessä. Riskejä ottavassa tietokulttuurissa tietoa hyödynnetään myös organisaation ulkopuolelta ja kannustetaan luovien, innovatiivisten ratkaisujen käyttöön toiminnan kehittämisessä. Avoimen, vuorovaikutteisemman tietokulttuurin kehittäminen rakentaa käytännössä tapoja, joilla parannetaan organisaation kykyä oppia ja kehittää toimintaansa.

Tietokulttuurin merkitys sote-organisaatioiden toiminnan ja uudistumisen kannalta on varsin keskeinen ja muutosta mahdollistava. Tietokulttuurin kehittäminen avoimeen, hyväksyvään ja kehittämistietoa arvostavaan suuntaan nähdään keskeisenä keinona ratkaista rakenteisiin perustuvan, siiloutuneen tietotoiminnan ongelmia. Olennaista on kehittää sellaista tietotoimintaa ja erityisesti sitä mahdollistavaa johtamista, joka kannustaa tiedon luomiseen ja jakamiseen, ja joka kykenee vastaamaan joustavasti erityyppisiin muutostarpeisiin. Tietokulttuurin ulottuvuuksien ja ongelmakohtien tunnistaminen toimii kehittämistyön lähtökohtana, mihin voi käytännössä liittyä esimerkiksi tietovirtojen sujuvoittamista, tietokuilujen tai -aukkojen poistamista, parhaiden käytäntöjen edistämistä ja asiantuntijaverkostoihin pohjautuvan yhteistyön lisäämistä. Kulttuuria rakentavat myös nimitykset, joilla ongelmallisia asioita kutsutaan, kuten potilasvahinko, tiedon hukkaaminen tai tiedon panttaaminen. Pienetkin tekijät luovat kuvaa kulttuurista ja ilmapiiristä, ja voivat saada aikaan muutosta, jolloin myös johtamisviestinnän kieleen olisi hyvä suunnata huomiota. Kivisen (2008) tutkimuksessa vastaajat, jotka kokivat kulttuurin kehittämismyönteiseksi ja yhteiseen vastuuseen perustuvaksi, näkivät tiedon organisoinnin ja jakamisen toteutuvan muita paremmin. Tulos korostaa tulkinnallisuutta ja johtajien ja esimiesten roolia, mutta myös pienten askelten merkitystä tieto- ja toimintakulttuurin kehittämisessä sote-muutoksen kontekstissa. 
Sote-organisaatioilla on tutkimuksemme mukaan erinomaisen hyvät edellytykset kehittää tietotoimintaa avoimeksi, luotettavaksi ja rajoja ylittävään vuorovaikutteisuuteen, sillä tiedon ja tietoperustaisuuden merkitys näkyy vahvana arvoissa ja vuorovaikutuksellisuutta pidetään tärkeänä tietotoiminnassa. Tämä edellyttää valmiuksia kokonaisvaltaiseen tietotoiminnan, prosessien, rakenteiden, ihmisten ja johtamisen tarkasteluun, jotka kuuluvat osaksi inhimillistä, vuorovaikutteista organisaatiotoimintaa. On tärkeää, että tietoon ja johtamiseen liittyvistä arvoista ja ongelmista keskustellaan, sillä esimerkiksi tietoprosesseihin tai tiedon saatavuuteen liittyvät ongelmat voivat heikentää luottamusta ja sitä kautta ihmisläheisen, vuorovaikutteisen johtamisen onnistumista.

Tutkimuksen luotettavuuden pohdinnassa tulee lähteä liikkeelle valitusta mallinnuksesta. Selvitimme Choon (2013) tietokulttuuri -mallinnuksen sovellettavuutta suomalaisten sote-organisaatioiden tutkimuksessa. Tutkimuskysymyksien mukaiset odotuksemme yleisellä tasolla olevien tietokulttuurien ulottuvuuksien kuvaamisesta täyttyivät. Ulottuvuuksien kuvailulla ja täydentävällä laadullisella aineistolla voidaan nostaa esiin ja näkyväksi kehittämisen kohteita organisaatiotasolla. Sen sijaan Choon (emt.) esittämä hypoteesi kahdesta selkeästi painottuvasta tietokulttuurin ulottuvuudesta ei tutkimuksessamme toteutunut. Tulosten luotettavuuden tarkastelussa voidaankin kriittisesti pohtia, kuinka kattavasti valitsemamme pieni määrä muuttujia kuvaa tutkittavan näkökulman tilaa tutkimuskohteissa. Yhdistämällä useampi muuttuja jokaisen näkökulman alle voitaisiinkin lähtökohtaisesti saada kattavampaa tietoa, ja tämän täytyisi luonnollisesti olla tavoitteena jo kyselyn suunnitteluvaiheessa. Monipuolisempaa mitta-

\section{LÄHTEET}

Ackoff, Russell L. (1989). From Data to Wisdom, Presidential Address to ISGRS, June 1988. Journal of Applied Systems Analysis, 16, 3-9.

Barnard, Pamela, Napier, Judith \& Zipperer, Lorri (2014). What is Knowledge? In Zipperer, Lorri (Ed.). Knowledge Management in Health Care. Dorchester: Routledge. ristoa voidaankin tämän tutkimuksen perusteella suositella jatkotutkimuksissa toteutettavaksi. Lisäksi luotettavuutta todennäköisesti paransi täydentävä laadullinen aineisto, mitä ei alkuperäisessä mallinnuksessa nostettu esiin, joskin myös sen merkitystä olisi mahdollista vahvistaa jatkotutkimuksessa.

Lisäksi luotettavuustarkastelussa ja jatkotutkimustarpeissa on huomioitava tulosten yksikkökohtainen vaihtelu. Luotettavuutta luonnollisesti lisäisi mallin tutkimus useammissa sote-organisaatioissa sekä tulosten ulottaminen yksikkötasolle. Organisaatiotasoinen tarkastelu antaa viitteitä tietokulttuurin ulottuvuuksista ja tietotoiminnan heikkouksista yleisesti ottaen, mikä sekin on tärkeää tietoa, mutta konkreettinen kehittämistyö edellyttäisi yksikkötason tutkimustietoa tietokulttuurin toimivuudesta.

Kokonaisuutena tutkimuksemme tietokulttuurin ulottuvuuksista sote-organisaatioissa osallistuu vuorovaikutteisuuteen liittyvään keskusteluun tietojohtamisen ja tiedolla johtamisen hallintotieteellisessä kentässä. Uudistumisen ja muutosvalmiuden kannalta on tärkeää tunnistaa tiedon kanssa toimimisen tapoja, esteitä ja mahdollisuuksia johtamisen eri tasoilla sekä työyhteisöissä. Tietokulttuuri tarjoaa toimivan ja monia ajankohtaisia työelämän ongelmia koostavan näkökulman johtamisen ja työyhteisöjen tutkimukseen, jolla olisi annettavaa laajemmallekin yleisölle. Tutkimuksemme pohjalta voimmekin todeta, että tietokulttuuri on käsitteellisesti kiinnostava ja kytkettävissä tieto- ja tietoperustaisen johtamisen ohella moniin hallinnon ja johtamisen tutkimuksen aloihin, kuten henkilöstöjohtamiseen, johtamisen psykologiaan, muutosjohtamiseen, viestintään ja vuorovaikutukseen tai työyhteisöjen kehittämiseen.

Becerra-Fernandez, Irma \& Sabherwal, Rajiv (2015). Knowledge Management. Systems and Processes. New York: Routledge.

Burgess, Nicola \& Radnor, Zoe (2013). Evaluating Lean in healthcare. International Journal of Health Care Quality Assurance, 26(3), 220-235. Cameron, Kim S. \& Quinn, Robert E. (2011). 
Diagnosing and changing organizational culture: Based on the competing values framework. Reading, MA: Jossey Bass.

Choo, Chun Wei (2006). The knowing organization. How organizations use information to construct meaning, create knowledge, and make decisions. USA: Oxford University Press.

Choo, Chun Wei (2013). Information culture and organizational effectiveness. International Journal of Information Management, 33, 775779.

Curry, Adrienne \& Moore, Caroline (2003). Assessing information culture - an exploratory model. International Journal of Information Management, 23, 91-110.

Cyr, Sylvio \& Choo, Chun Wei (2010). The individual and social dynamics of knowledge sharing: an exploratory study. Journal of Documentation, 66(6), 824-846.

Davenport, Thomas H. \& Prusak, Laurence (2000). Working Knowledge: How Organizations Manage What They Know. Boston: Harvard Business School Press.

Davies, Huw T.O., Nutley Sandra M. \& Mannion, Russell (2000). Organisational culture and quality of health care. Quality in Health Care, 9(2), 111-119.

Dupuy, Francois (2004). Sharing Knowledge. The why and how of organizational change. Hampshire: Palgrave Macmillan.

Hislop, Donald (2013). Knowledge Management in Organizations. A critical introduction. Oxford: Oxford University Press.

Jalonen, Harri (2015). Tiedolla johtamisen näyttämö ja kulissit. Teoksessa Virtanen, Petri, Stenvall, Jari \& Rannisto, Pasi-Heikki (toim.). Tiedolla johtaminen hallinnossa. Teoriaa ja käytäntöjä. Tampere: Tampereen yliopistopaino Oy - Juvenes Print.

Johnston, Erik W. (ed. 2015). Governance in the Information Era. Theory and Practice of Policy Informatics. New York: Routledge.

Jylhä, Virpi (2017). Information Management in Health Care. A Model for Connecting Information Culture and Patient Safety. Publications of the University of Eastern Finland, 140. Kuopio: University of Eastern Finland.

Kangas, Riikka (2018). Lean-ajattelun käyttöönoton organisaatiokulttuuriset tekijät julkisessa sairaalassa. Hallinnon tutkimus, 37(4), 244-256.

Kesti, Marko \& Syväjärvi, Antti (2010). Human tacit signals at organization performance development. Industrial Management \& Data Systems, 110(2), 211-229.
Kim, Yong-Mi, Newby-Bennett, Donna \& Song, Hee-Joon (2012). Knowledge sharing and institutionalism in the healthcare industry. Journal of Knowledge Management, 16(3), 480-494.

Kinnunen, Juha (2017). Organisaatiokulttuuri ja johtaminen. Teoksessa Rissanen, Sari \& Lammintakanen, Johanna (toim.). Sosiaali- ja terveysjohtaminen (167-182). Helsinki: Sanoma Pro Oy.

Kivinen, Tuula (2008). Tiedon ja osaamisen johtaminen terveydenhuollon organisaatioissa. Kuopion yliopiston julkaisuja E. Yhteiskuntatieteet 158. Kuopio: Kopijyvä.

Kogut, Bruce \& Zander, Udo (1992). Knowledge on the firm, combinative capabilities, and the replication on technology. Organization Science, 3(3), 383-397.

Laihonen, Harri, Hannula, Mika, Helander, Nina, Ilvonen, Ilona, Jussila, Jari, Kukko, Marianne, Kärkkäinen, Hannu, Lönnqvist, Antti, Myllärniemi, Jussi, Pekkola, Samuli, Virtanen, Pasi, Vuori, Vilma \& Yliniemi, Terhi (2013). Tietojohtaminen. Tampereen teknillinen yliopisto. Tampere. Haettu sivulta https://repo.tuni.fi/ bitstream/handle/10024/116695/tietojohtaminen.pdf 5.1.2020.

Laitinen, Ilpo (2016). Työn mielekkyyden ja mahdollisuuksien tukeminen johtamisella. Teoksessa Syväjärvi, Antti \& Pietiläinen, Ville (toim.). Inhimillinen ja tehokas sosiaali- ja terveysjohtaminen (s. 147-186). Tampere: Tampere University Press.

Lambe, Patrick (2007). Organising Knowledge: Taxonomies, Knowledge and Organisational Effectiveness. Oxford: Chandos Publishing.

Lauri, Liia, Heidmets, Mati \& Virkus, Sirje (2016). The information culture of higher education institutions: the Estonian case. Information Research 21(3), paper 722.

Li, Meng-Hao \& Feeney, Mary K. (2014). Adoption of electronic technologies in local U.S. governments: Distinguishing between E-services and communication technologies. American Review of Public Administration, 44(1), 75-91.

Liu, Alan (2009). The Laws of Cool: Knowledge Work and the Culture of Information. Chicago: University of Chicago Press.

Nonaka, Ikujiro \& Takeuchi, Hirotaka (1995). The Knowledge-creating Company. Oxford: Oxford University Press.

Markova, Maiju (2005). Tiedon merkitys organisaation muuttumiselle ja uudistumiselle. Research reports 27. Tampereen teknillinen yliopisto ja Tampereen yliopisto. Tampere: Cityoffset $\mathrm{Oy}$. 
Maula, Marjatta \& Peltoniemi, Mirva (toim. 2005). Tietointensiivinen palvelutoiminta: näkökulmina kompleksisuus ja tiedonhallinta. Research reports 25 . Tampereen teknillinen yliopisto ja Tampereen yliopisto. Tampere: Cityoffset Oy.

Marjanovic, Olivera (2011). Improving Knowledge-Intensive Health Care Processes Beyond Efficiency. ICIS 2011 proceedings, 10.

Mertala, Sirpa (2011). Yhdessä tietämisen episodeja. Terveydenhuollon kompleksiset työympäristöt. Acta Universitatis Lapponiensis 201. Rovaniemi: Lapin yliopistokustannus.

Oliver, Gillian (2008). Information culture: exploration of differing values and attitudes to information in organisations. Journal of Documentation, 64(3), 363-385.

Pietiläinen, Ville \& Salmi, Ilkka (2016). An integrative discourse perspective on positive leadership in public health care. Leadership in Health Services, 30(1), 44-58.

Pynes, Joan E. \& Lombardi, Donald N. (2011). Human resources management for health care organizations. A strategic approach. USA: Jossey-Bass.

Prusak, Laurence (1997). Knowledge in Organizations. USA: Butterworth-Heinemann.

Rissanen, Sari \& Lammintakanen, Johanna (toim. 2017). Sosiaali- ja terveysjohtaminen. Helsinki: Sanoma Pro Oy.

Rytilä, Maari (2011). Tietoperustainen johtaminen palvelutoiminnan suunnittelussa julkisella terveydenhuoltoalalla. Acta Universitatis Lapponiensis 214. Lapin yliopisto. Rovaniemi: Lapin yliopistokustannus.

Saranto, Kaija ja Kuusisto-Niemi, Sirpa (2017). Tiedon hallinta johtamisessa. Teoksessa Rissanen, Sari \& Lammintakanen, Johanna (toim.). Sosiaali- ja terveysjohtaminen (217-236). Helsinki: Sanoma Pro Oy.

Smallwood, Robert F. (2014). Information Governance. Concepts, Strategies, and Best Practices. Hoboken: John Wiley \& Sons.

Snowden, David (2005). Stories from the frontier. E-CO, 7(3-4), 155-165.

Soklaridis, Sophie (2013). Improving hospital care: are learning organizations the answer? Journal of Health Organization and Management, 28(6), 830-838.

Steventon, Adam, Jackson, Thomas W., Hepworth, Mark, Curtis, Stephen, \& Everitt, Claire (2012). Exploring and modelling elements of information management that contribute towards making positive impacts: An outcome based approach for senior managers in a local government setting. International Journal of Information Management, 32(2), 158-163.
Ståhle, Pirjo \& Grönroos, Mauri (2000). Dynamic Intellectual Capital. Knowledge Management in Theory and Practice. Vantaa: WSOY.

Sundqvist, Anneli \& Svärd, Proscovia (2016). Information culture and records management: a suitable match? Conceptualizations of information culture and their application on records management. International Journal of Information Management, 36(1), 9-15.

Syväjärvi, Antti, Leinonen, Jaana, Kivivirta, Ville \& Kesti, Marko (2017). The latitude of information management in local government: Views of local government managers. International Journal of Electronic Government Research, 13(1), 69-85.

Syväjärvi, Antti \& Pietiläinen, Ville (toim. 2016). Inhimillinen ja tehokas sosiaali- ja terveysjohtaminen. Tampere: Tampere University Press.

Syväjärvi, Antti \& Vakkala, Hanna (2019). Myönteisyys ja voimavaraisuus ihmisten johtamisessa. Teoksessa Pietiläinen, Ville \& Syväjärvi, Antti (toim.). Johtamisen psykologia (201-235). Jyväskylä: PS-kustannus.

Syväjärvi, Antti, Vakkala, Hanna \& Stenvall, Jari (2013). Tiedon hallintaa ja positiivisuutta henkilöstöjohtamiseen julkisen sektorin terveydenhuollossa. Teoksessa Ollila, Seija \& Raisio, Harri (toim.) Hyvinvointijärjestelmät muuttuvassa toimintaympäristössä (s. 151-170). Acta Wasaensia 277, Sosiaali- ja terveyshallintotiede 8. Vaasan yliopisto. Vaasa: Suomen yliopistopaino - Juvenes Print Oy.

Tasselli, Stefano (2014). Social Networks of Professionals in Health Care Organizations: A Review. Medical Care Research and Review, 71(6), 619-660.

Vakkala, Hanna \& Palo, Miia (2016). Tietoperustaisuus ja tietokulttuuri johtamistyössä. Teoksessa Syväjärvi Antti \& Pietiläinen Ville (toim.). Inhimillinen ja tehokas sosiaali- ja terveysjohtaminen (s. 187-226). Tampere: Tampere University Press.

Valkonen, Marjo-Riitta., Kinnunen, Ulla-Mari \& Saranto, Kaija (2018). Tiedonhallinnan prosessimallin hyödyntäminen sosiaali- ja terveydenhuollon tiedonhallintaa koskevissa tutkimuksissa. Finnish Journal of eHealth and eWelfare, 10(2-3), 285-296.

van Duivenboden, Hein \& Thaens, Marcel (2008). ICT-driven innovation and the culture of public administration: A contradiction in terms? Information Polity, 13(3-4), 213-232.

Vick, Thais Elaine, Nagano, Marcelo Seido \& Popadiuk, Silvio (2015). Information culture and its influences in knowledge creation: Evidence from university teams engaged in 
collaborative innovation projects. International Journal of Information Management, 35, 292298.

Virtanen, Petri, Stenvall, Jari \& Rannisto, PasiHeikki (toim. 2015). Tiedolla johtaminen hallinnossa. Teoriaa ja käytäntöjä. Tampere: Tampereen yliopistopaino Oy - Juvenes Print.

Virtanen, Juha V. (2010). Johtajana sairaalassa. Johtajan toimintakenttä julkisessa erikoissairaalassa keskijohtoon ja ylimpään johtoon kuuluvien lääkäri- ja hoitajataustaisten johtajien näkökulmasta. Turun Kauppakorkeakoulu. Turku: Uniprint.
Vuori, Jari (toim. 2005). Terveys ja johtaminen. Terveyshallintotiede terveydenhuollon työyhteisössä. Porvoo: WSOY.

Wehrens, Rik, Bekker, Marleen, \& Bal, Roland (2014). Hybrid management configurations in joint research. Science, Technology \& Human Values, 39(1), 6-41.

Zipperer, Lorri (ed. 2014). Knowledge Management in Health Care. Dorchester: Routledge. 